Article

\title{
Enzymatic Hydrolysis of Softwood Derived Paper Sludge by an In Vitro Recombinant Cellulase Cocktail for the Production of Fermentable Sugars
}

\author{
Samkelo Malgas ${ }^{1}\left(\mathbb{D}\right.$, Shaunita H. Rose ${ }^{2}$, Willem H. van $\mathrm{Zyl}^{2}{ }^{2}$ and Brett I. Pletschke ${ }^{1, *(1)}$ \\ 1 Enzyme Science Programme (ESP), Department of Biochemistry and Microbiology, \\ Rhodes University, Grahamstown 6140, South Africa; samkelomalgas@yahoo.com \\ 2 Department of Microbiology, Stellenbosch University, Stellenbosch 7600, South Africa; \\ shrose@sun.ac.za (S.H.R.); whvz@sun.ac.za (W.H.v.Z.) \\ * Correspondence: b.pletschke@ru.ac.za; Tel.: +27-46-603-8081
}

Received: 3 June 2020; Accepted: 19 June 2020; Published: 11 July 2020

\begin{abstract}
Paper sludge is an attractive biomass feedstock for bioconversion to ethanol due to its low cost and the lack of pretreatment required for its bioprocessing. This study assessed the use of a recombinant cellulase cocktail (mono-components: S. cerevisiae-derived PcBGL1B (BGL), $\mathrm{TeCel7A}$ (CBHI), ClCel6A (CBHII) and TrCel5A (EGII) mono-component cellulase enzymes) for the efficient saccharification of softwood-derived paper sludge to produce fermentable sugars. The paper sludge mainly contained $74.3 \%$ moisture and $89.7 \%$ (per dry mass (DM)) glucan with a crystallinity index of $91.5 \%$. The optimal protein ratio for paper sludge hydrolysis was observed at 9.4: 30.2: 30.2: $30.2 \%$ for BGL: CBHI: CBHII: EGII. At a protein loading of $7.5 \mathrm{mg} / \mathrm{g}$ DW paper sludge, the yield from hydrolysis was approximately $80 \%$, based on glucan, with scanning electron microscopy micrographs indicating a significant alteration in the microfibril size (length reduced from $\geq 2 \mathrm{~mm}$ to $93 \mu \mathrm{m}$ ) of the paper sludge. The paper sludge hydrolysis potential of the Opt CelMix (formulated cellulase cocktail) was similar to the commercial Cellic CTec ${ }^{\circledR}$ and Celluclast ${ }^{\circledR} 1.5 \mathrm{~L}$ cellulase preparations and better than Viscozyme ${ }^{\circledR}$ L. Low enzyme loadings $(15 \mathrm{mg} / \mathrm{g}$ paper sludge) of the Opt CelMix and solid loadings ranging between 1 to $10 \%(w / v)$ rendered over $80 \%$ glucan conversion. The high glucose yields attained on the paper sludge by the low enzyme loading of the Opt CelMix demonstrated the value of enzyme cocktail optimisation on specific substrates for efficient cellulose conversion to fermentable sugars.
\end{abstract}

Keywords: cellulase; cellulose; paper sludge; Saccharomyces cerevisiae; synergism

\section{Introduction}

The production of bioethanol from lignocellulosic biomass or lignocellulose-derived wastes is one of the most promising alternatives to conventional fossil fuels [1]. Lignocellulosic biomass is an ideal feedstock for bioethanol production because it is an abundant renewable source, obtainable at low cost and generally not considered to compete with food sources [1,2].

Paper sludge (waste fibre) is a residual stream produced by pulp mills [3]. Currently, it is utilised in either landfilling or incineration to generate energy for pulp mills [4]. Paper sludge has a high carbohydrate and low lignin content which eliminates the requirement of additional thermochemical pretreatment steps. Paper sludge has high potential and value as a suitable feedstock for the production of lactic acid and bioethanol [5]. The latter requires the enzymatic hydrolysis of paper sludge by cellulases to fermentable sugars which can subsequently be fermented by yeast into bioethanol [3]. Four key cellulase activities working synergistically are required for cellulose utilisation; exo-glucanases 
(CBHI and CBHII) target the crystalline regions of cellulose and produce cellobiose in a processive manner, while endo-glucanases randomly cleave internal sites at amorphous regions to produce long-chain cello-oligomers, $\beta$-glucosidases then process the products from the aforementioned enzymes into glucose [6,7].

In spite of the progress achieved by enzyme manufacturers in lowering enzyme production costs, cellulases still constitute a significant portion of the final bioethanol production costs. Many strategies have been developed to reduce enzyme cost, including enzyme recycling, improving enzyme synergism through synthetic cocktail design and enzyme engineering [8-10]. Synthetic cocktails with improved enzyme synergism is one of the strategies that can be implemented to lower the amount of enzyme required for hydrolysis [8].

Numerous studies have successfully produced cellulase mono-components; endo-glucanase, exo-glucanases (CBHI and CBHII) and $\beta$-glucosidases in Saccharomyces cerevisiae strains using heterologous gene expression [11-13]. More recent studies focused on using and improving S. cerevisiae wild type and industrial strains for second-generation (2G) bioethanol production by targeting ideal traits, such as the secretory capacity of heterologous cellulase enzymes through evolutionary and genetic engineering, and mutagenesis [14-17]. However, the optimum enzyme ratios for specific cellulosic substrates are crucial for developing more efficient consolidated bioprocessing (CBP) yeast strains. In this study, mono-component recombinant cellulases-S. cerevisiae-derived PcBGL1B (BGL), TeCel7A (CBHI), ClCel6A (CBHII) and TrCel5A (EGII)—were produced in S. cerevisiae Y294 strains and partially purified for use in formulating an enzyme cocktail for the efficient deconstruction of paper sludge. The performance of the formulated cellulase cocktail was compared to that of different commercially available cellulase cocktails in terms of its hydrolytic performance on paper sludge. Furthermore, the effect of higher amounts of solids and enzyme loadings on the hydrolysis efficiency of the cocktail was studied to optimise the conversion process.

\section{Results and Discussion}

\subsection{Composition and Structural Analysis of Paper Sludge}

The chemical composition and structural characterisation (crystallinity and cellulase accessibility) of paper sludge was assessed and is displayed in Table 1 . The paper sludge contained a dry mass (DM) of $24.7 \%$ of the total mass, similar to that reported for paper sludge derived from a mixture of pine, cypress and eucalyptus (65\% moisture content) [1]. The carbohydrate fraction was the major component of the dry mass (DM) of paper sludge, with glucan estimated at $89.7 \%$ followed by hemicellulose, lignin and ash on dry mass basis.

Table 1. Chemical composition as percentage of dry mass basis and structural analysis of paper sludge.

\begin{tabular}{cc}
\hline Component/Property & Content/Accessibility \\
\hline Glucan * & $89.7 \%$ \\
Mannan * & $2.73 \%$ \\
Xylan * & $1.65 \%$ \\
Galactan * & $0.08 \%$ \\
Arabinan * & $\mathrm{Nd}$ \\
Lignin * & $0.8 \%$ \\
Ash * & $1.7 \%$ \\
Moisture & $74.3 \%$ \\
Crystallinity index & $91.5 \%$ \\
Substrate accessibility $(\mathrm{mg} / \mathrm{g})$ & $87 \mathrm{mg} / \mathrm{g}$ \\
\hline
\end{tabular}

Not detected $(\mathrm{Nd}) .{ }^{*}=$ percentage of DW.

X-ray diffraction (XRD) analysis was used to determine the type of cellulose and the crystallinity index of the paper sludge biomass. Based on the XRD pattern (four main peaks at 1-10, 110, 200 
and 004) displayed by paper sludge, it could be deduced that the glucan content of the biomass is in the form of cellulose I $\beta$ (Figure 1).

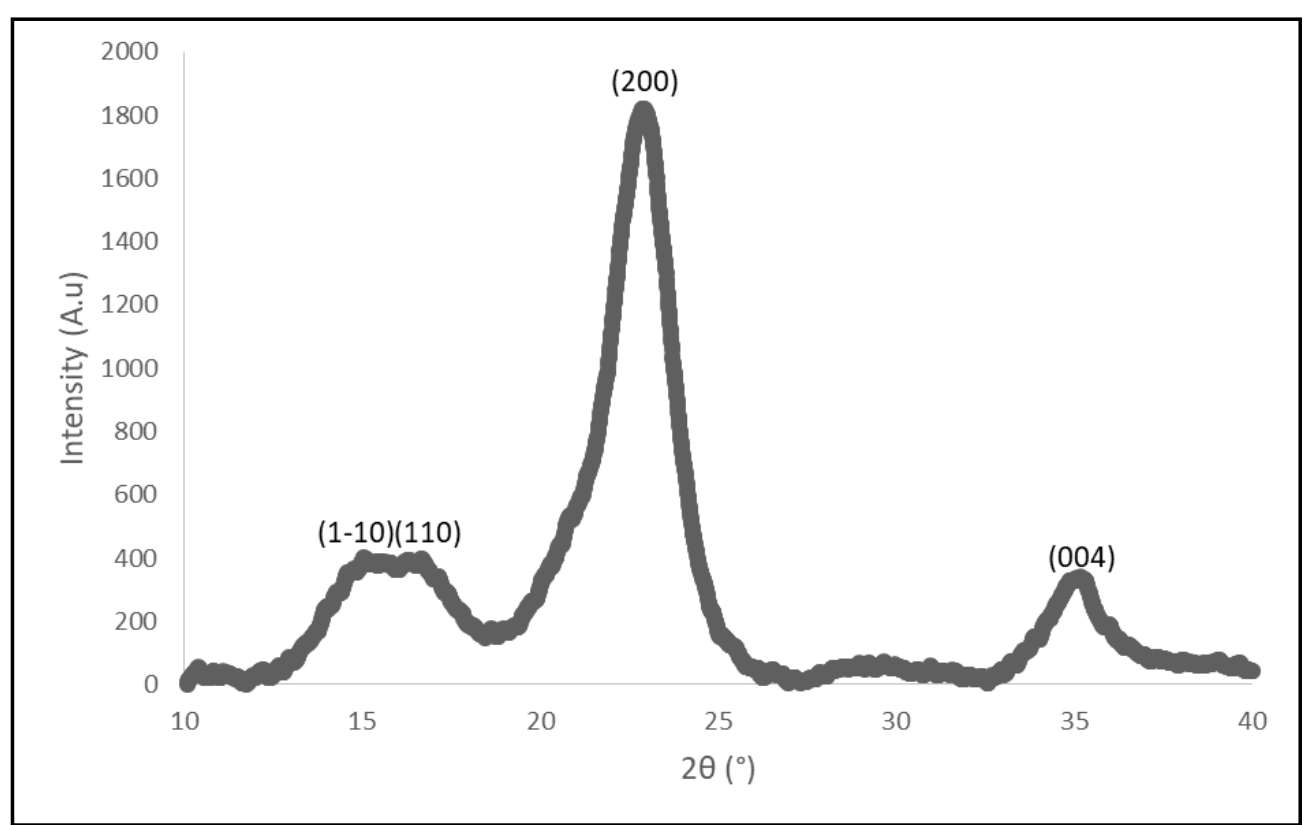

Figure 1. An X-ray diffraction pattern of paper sludge illustrating four main peaks (1-10, 110, 200 and 004) specific for cellulose I $\beta$.

The crystallinity index (CrI) of the paper sludge was estimated using the peak height method as previous described $[18,19]$. The CrI value of the paper sludge was estimated at approximately $91.5 \%$ (Table 1), similar to that of Avicel PH-101 (model cellulose I $\beta$ biomass) with 89 to $92 \%$ reported by Park et al. [18] and Malgas et al. [20]. Biomass with high cellulosic contents have higher CrI values compared to biomasses with lower cellulosic contents [21].

Furthermore, the accessibility of the paper sludge biomass to cellulases was evaluated using a modified version of Simon's staining method. Paper sludge was shown to be highly accessible to the crystalline cellulose-specific direct orange (DO) dye (see Table 1). The accessibility of paper sludge to DO $(87 \mathrm{mg} / \mathrm{g}$ ) was slightly higher than that previously reported for Avicel PH-101 (67 mg/g) [20]. This coincided with the slightly higher crystallinity index observed in paper sludge compared to that of Avicel PH-101.

\subsection{Enzyme Production and Substrate Specificities Using "Model" Substrates}

In this study, the S. cerevisiae-derived PcBGL1B (BGL), TeCel7A (CBHI), ClCel6A (CBHII) and $\operatorname{TrCel5A}$ (EGII) mono-component cellulase enzymes were individually produced under the transcriptional control of the enolase 1 gene (ENO1) promoter (constitutive expression) and concentrated to approximately $1.5 \mathrm{mg} / \mathrm{mL}$. Since the yeast strains were cultured in minimal media, very few other protein species were present in the concentrated culture supernatants containing the mono-component cellulase enzymes. To assess the relative purity of the cellulases upon ultrafiltration, they were separated by sodium dodecyl sulphate-polyacrylamide gel electrophoresis (SDS-PAGE) (Figure 2). The estimated molecular masses of the enzymes were approximately 80 and $140 \mathrm{kDa}(60 \mathrm{kDa}$ was expected as reported in the literature), $70 \mathrm{kDa}, 75 \mathrm{kDa}$ (heterogeneous in size due to hyper-glycosylation) and $54 \mathrm{kDa}$ for BGL, CBHI, CBHII and EGII, respectively, and corresponded to molecular masses determined previously [22,23]. Migration on SDS-PAGE that does not correlate with formula molecular masses, termed "gel shifting", is common for some proteins [24], this may explain why the anticipated molecular mass of BGL was not observed in Figure 2. 


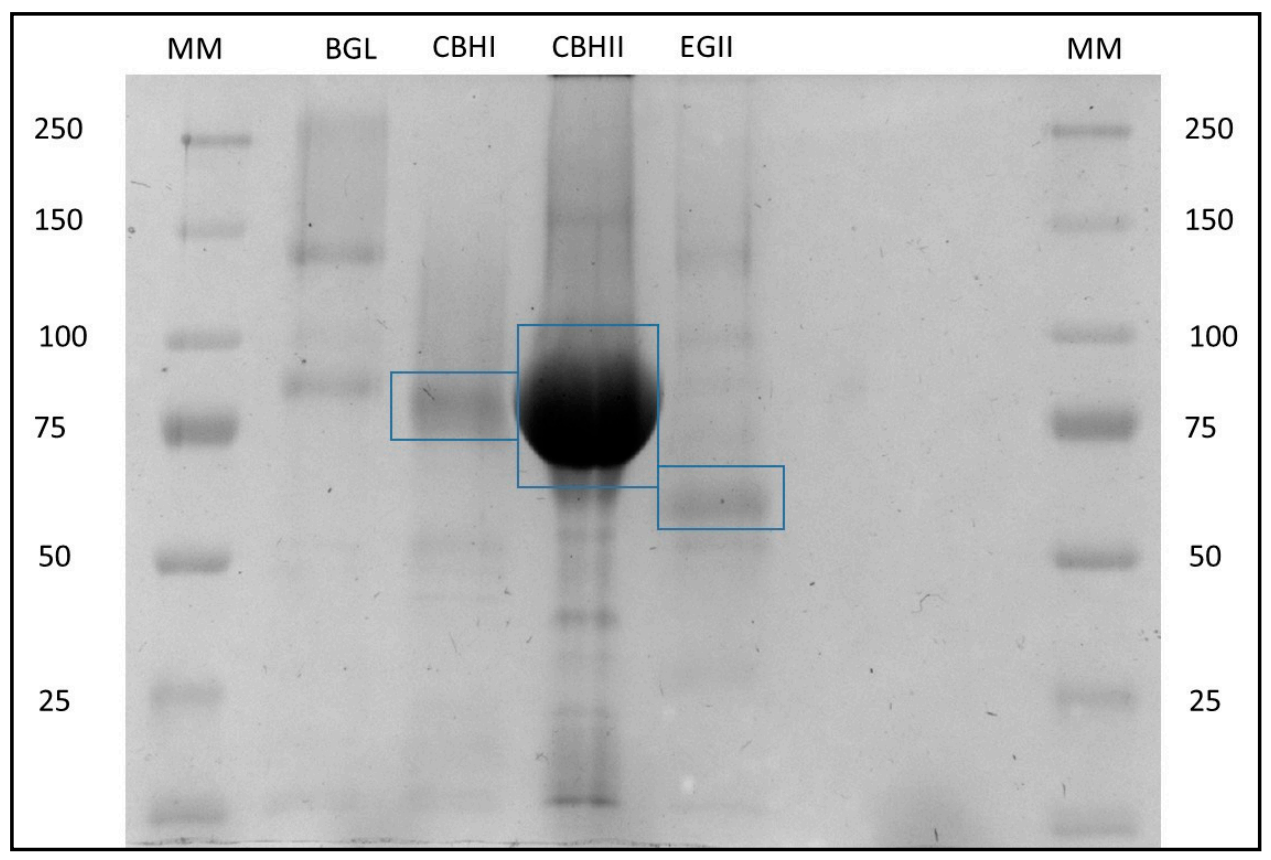

Figure 2. Denaturing 12\% sodium dodecyl sulphate-polyacrylamide gel electrophoresis (SDS-PAGE) of ultrafiltration-concentrated mono-component cellulases $(15 \mu \mathrm{L})$ visualised by Coomassie Brilliant Blue R-250 staining. Molecular mass marker (MM) (BioRad Precision Plus Protein Standards); the blue rectangles represent the identified protein molecular masses corresponding to the literature.

The cellulases were tested for their specific activities using different substrates at $50{ }^{\circ} \mathrm{C}$ in $50 \mathrm{mM}$ sodium citrate buffer, $\mathrm{pH} 5.0$, since these conditions assured sufficient and stable activity of all the enzymes assessed (data not shown). The specific activities of the individual recombinant cellulases on model cellulosic substrates is displayed in Table 2 .

Table 2. Specific activities (U/mg protein) of the cellulase enzymes on model substrates. The underlined values are the specific activities expected (based on the literature) for each enzyme tested.

\begin{tabular}{cccccc}
\hline Enzyme & CMC-Na & Cellopentaitol & $p$ NPC & $p$ NPG & Reference \\
\hline BGL & 0.67 & - & 5.74 & 56 & {$[10,14,25]$} \\
CBHI & 0.24 & $\mathrm{Nd}$ & 0.20 & 0.35 & {$[12,26]$} \\
CBHII & 1.69 & 0.38 & $\mathrm{Nd}$ & 0.11 & {$[26]$} \\
EGII & 44 & - & $\mathrm{Nd}$ & 0.11 & {$[10,12,14,26]$} \\
\hline
\end{tabular}

Not detected (Nd). Not determined (-).

The $\beta$-glucosidase, BGL, showed the highest activity ( $56 \mathrm{U} / \mathrm{mg}$ ) on 4-nitrophenyl- $\beta$-D-glucopyranoside ( $p$ NPG), with some minor activity $(5.74 \mathrm{U} / \mathrm{mg}$ ) observed on 4-nitrophenyl- $\beta$-D-cellobioside ( $p$ NPC) (Table 2). CBHI displayed comparable activities $(\sim 0.3 \mathrm{U} / \mathrm{mg})$ on carboxymethylcellulose sodium (CMC-Na), $p$ NPC and $p$ NPG. The $\beta$-glucosidase activity displayed by CBHI was unexpected as the enzymes are reported to require at least a minimum of three subsites to initiate catalysis $[27,28]$. CBHII, on the other hand, displayed activity on both CMC-Na and cellopentaitol. The endo-glucanase, EGII, displayed high activity ( $44 \mathrm{U} / \mathrm{mg}$ ) on CMC-Na. Overall, the activities of the cellulases were generally in agreement with the literature [26].

\subsection{Enzyme Cocktail Formulation}

Paper sludge hydrolysis by CBHI or CBHII and/or EGII was performed in the presence of BGL and the concentration of glucose released was measured after $48 \mathrm{~h}$. A BGL dosage of $10 \%$ of the overall cellulase loading was found to be sufficient for converting all the cello-oligosaccharides into 
glucose (data not shown), and as a result, this BGL loading was used in all subsequent paper sludge hydrolysis evaluations.

Numerous studies have evaluated synergism between cellulolytic enzymes and the hydrolysis of cellulose, particularly: (i) exo-exo synergism, whereby cellobiohydrolases (CBHs) hydrolyse cellulose at opposite cellulose fibril ends and (ii) endo-exo synergism between endo-glucanases (EGs) and $\mathrm{CBHs}$, whereby endo-glucanases cleave amorphous regions of cellulose exposing more chain ends for CBHs $[6,29]$.

In this study, enzyme synergism between the cellulolytic enzymes, BGL, CBHI, CBHII and EGII was assessed using paper sludge as a substrate. These experiments were conducted in order to formulate a "cellulolytic core set" for the efficient hydrolysis of paper sludge cellulose to glucose. The binary enzyme combinations between $\mathrm{CBHI}$ and $\mathrm{CBHII}$, were synergistic at all enzyme combinations considered, with an increase from $2.5-2.9 \mathrm{mg} / \mathrm{mL}$ of glucose by the individual enzymes at $100 \%$ dosage to approximately 3.7 to $4.0 \mathrm{mg} / \mathrm{mL}$ of glucose release by the combinations of CBHI and CBHII (Figure 3). The yield obtained by the optimal binary combination (CBHI and CBHII at 50: 50\%) corresponded to approximately $22 \%$ glucan conversion after $48 \mathrm{~h}$.

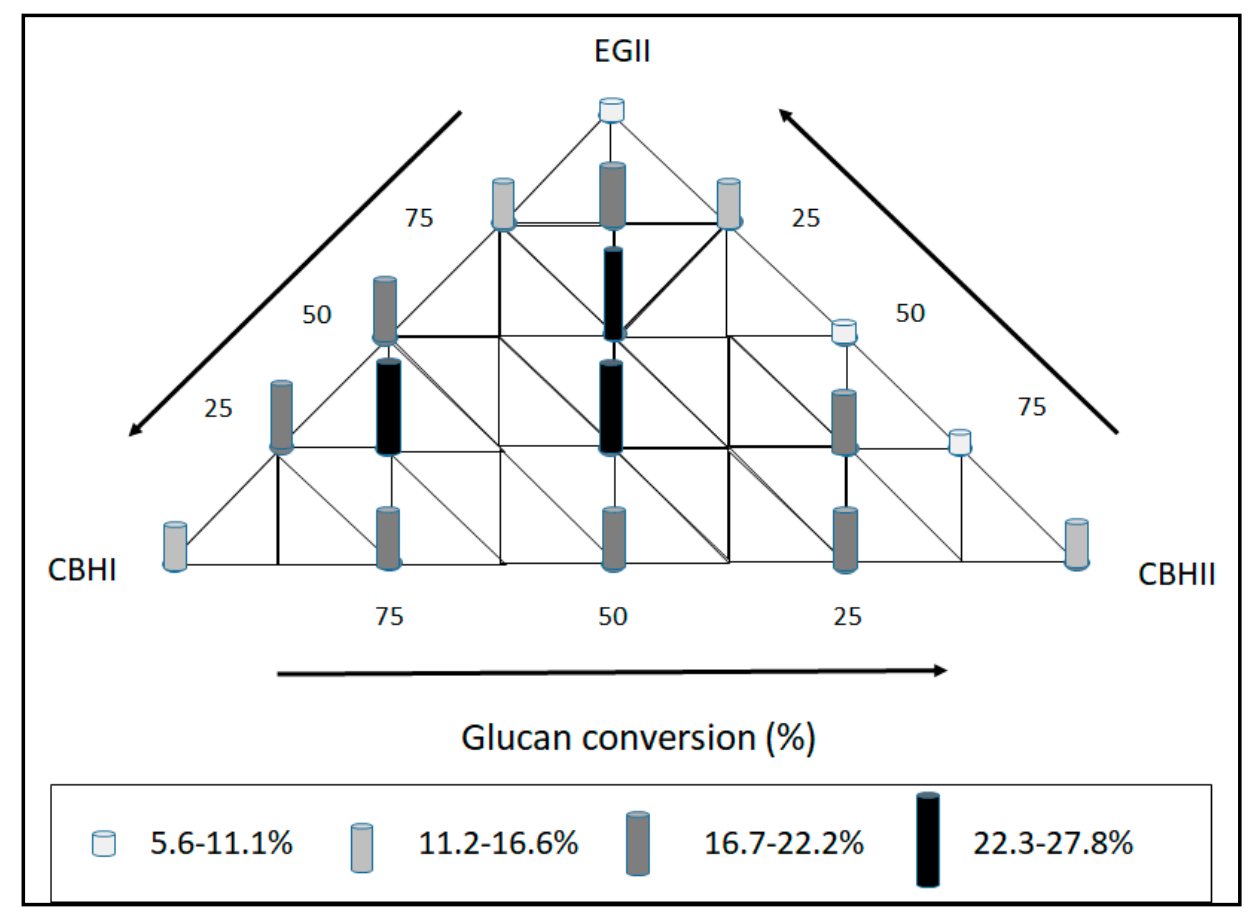

Figure 3. Glucose yields obtained from the optimisation of the formulated cellulase cocktail (TeCel7A (CBHI), ClCel6A (CBHII) and $\operatorname{TrCel5A}(\mathrm{EGII}))$ on the hydrolysis of $2 \%$ ( $w / v$, dry mass basis) paper sludge for $48 \mathrm{~h}$ at $50{ }^{\circ} \mathrm{C}$, at a protein loading of $1.875 \mathrm{mg} / \mathrm{g}$ biomass with PcBGL1B (BGL) at $10 \%$ protein loading. All experiments were performed in quadruplicate and the mean values were calculated. The different shades of the bars indicate data sets that exhibited differences which were statistically significant (one-way ANOVA, $p<0.05$ ).

The classical exo-exo-cellulase model of synergistic enzymatic hydrolysis of cellulose proposes that CBHI starts catalysis at the reducing end of cellulose chains, whereas CBHII initiates activity on the non-reducing, opposite chain ends of cellulose, and has been confirmed [30,31].

Exo-cellulase (CBHI or CBHII) and endo-cellulase (EGII) synergism was also assessed during paper sludge hydrolysis. Figure 3 indicates that CBHI synergised with EGII and that the enzyme combinations where $\mathrm{CBHI}$ was present at a higher protein ratio to EGII, released the most glucose. At $75 \%$ CBHI to $25 \%$ EGII protein dosage, approximately $3.3 \mathrm{mg} / \mathrm{mL}$ of glucose was released from $2 \%$ $(w / v)$ paper sludge, which corresponded to approximately $20 \%$ glucan conversion after $48 \mathrm{~h}$. 
According to Wood and McCrae (1979), the endo-exo-cellulase (s) model of synergism involves endo-cellulases (endo-glucanases) which attack the amorphous regions within cellulose, creating new and more chain ends for exo-cellulases (cellobiohydrolases I and or II) to attack [32,33]. In turn, exo-cellulases expose new amorphous regions within the bulk substrate and this then necessitates re-application of endo-cellulase activity. Data attesting to this interdependence between endo-glucanases and cellobiohydrolases during cellulose hydrolysis has been reported by others [7].

The CBHII to EGII combinations exhibited a lower level of glucose release than that exhibited by CBHII at $100 \%$ dosage $(2.5 \mathrm{mg} / \mathrm{mL})$, except for $25 \%$ CBHII to $75 \%$ EGII which released comparable glucose concentrations to $100 \%$ CBHII. It is possible that the CBHII could be competing with EGII for the same subsites (amorphous regions) on the paper sludge biomass since CBHII exhibited residual endo-glucanase activity when evaluated on CMC as substrate (see Table 2). As a result, this could have led to the anti-synergism (competition for the same binding sites) observed between the two cellulases during paper sludge hydrolysis (see Figure 3). Previous studies have reported that, in addition to the processive exo-activity from the non-reducing ends of cellulose chains, CBHIIs also occasionally have an endo-acting character $[6,34,35]$.

The ternary combinations of CBHI, CBHII and EGII generally showed the highest synergistic effect compared to the binary combinations of the same enzymes, with equal amounts of the three enzymes at 33.3: 33.3 : $33.3 \%$ or a higher proportion of cellobiohydrolases to EGII, particularly CBHI, releasing the highest glucose of approximately 4 and $5 \mathrm{mg} / \mathrm{mL}$ (22.2 and $27.8 \%$ glucan conversion), respectively, from paper sludge (Figure 3). Previous studies reported that the best enzyme combinations for cellulose hydrolysis were those with higher proportions of cellobiohydrolases (CBHI and CBHII) to the endo-glucanase, EGII $[36,37]$. Therefore, it seems that highly crystalline cellulosic biomass substrates such as paper sludge and Avicel cellulose require a higher proportion of the crystalline region-specific CBHs compared to the amorphous region-specific EGs (in this study, a ratio of $66.6 \% \mathrm{CBHI} / \mathrm{II}$ to $33 \%$ EGII was required). Two other substrate parameters; the degree of polymerisation (DP) and the fraction of $\beta$-glucosidic bonds accessible to cellulase, reaction time and enzyme loading seem to affect enzyme activity and the synergistic interactions between cellulase mono-components [38,39]. Väljamäe and co-workers [38] showed a correlation between the DP length and crystallinity of bacterial cellulose (BC) which was acid treated to various degrees, with a decrease in DP length being accompanied by an increase in CrI. In addition, the study showed that the relative activity of CBHI increased with an in increase in $\mathrm{CrI}$ and a decrease in the DP of $\mathrm{BC}$, while the relative activity of EG decreased with an increase in CrI and decrease in the DP of BC [38]. Similarly, Zhang and Lynd [39] showed that DP length of cellulose negatively affects the relative activity of exo-cellulases. In addition, the study showed that the EG concentration required for maximal synergism was 1 EG molecule to 17 exo-cellulase molecules. Den Haan and co-workers [22] also showed that a $3.4 \mathrm{mg} / \mathrm{g}$ biomass mixture of cellulases in a ratio of CBHII: CBHII: EGII of 11:5:1 released more glucose from Avicel compared to the individual mono-component cellulases at $>20 \mathrm{mg} / \mathrm{g}$ biomass. It has been postulated that the lower surface area limits EG adsorption on the surface of cellulose such that hydrolysis of many $\beta$-glucosidic bonds cannot occur until they are made accessible by the action of exo-cellulases such as CBHI or CBHII [40]. However, EGII was the largest contributing factor for successful synergism in the current study, as the enzyme was highly efficient even at very low dosages of 33.3\%, leading to nearly a doubling effect in paper sludge glucan conversion (see Figure 3). Similarly, previous studies have indicated that the addition of minute quantities of EG to CBHI or a mixture of CBHI and CBHII induced an increase in the saccharification of cellulose $[22,35,38]$.

CBHI appeared to be the only mono-component whereby an increase in its proportion in the ternary mixture was tolerated without affecting glucose yields (Figure 2). Similarly, a recent study observed that a minimum amount of surface area was needed for a single cellulase to be effective in hydrolysing cellulose and the hydrolytic efficiency will decrease when the total cellulase concentration exceeds saturation. Therefore, the use of excess enzymes should be avoided, even if their production costs are negligible [41]. The formulated cellulase cocktail consisting of 33.3:33.3:33.3\% of CBHI, CBHII 
and EGII with supplementation of BGL at 10\% protein dosage (henceforth referred to as Opt CelMix) was used in all subsequent studies.

\subsection{Effect of Opt CelMix Loading on the Hydrolysis Yields of Paper Sludge}

The Opt CelMix was used to hydrolyse the paper sludge $(2 \% w / v, D M)$ at different enzyme loadings (Figure 4). Saccharification yields of approximately $90 \%$ was obtained at protein loadings exceeding $7.5 \mathrm{mg}$ protein $/ \mathrm{g}$ biomass. The yields are in agreement with the more than $80 \%$ yield obtained from softwood (pine pulp) derived paper sludge after $48 \mathrm{~h}$ of hydrolysis at $50^{\circ} \mathrm{C}$ and $\mathrm{pH} 5.0$ with the NS-22086 multi-enzyme preparation (Novozymes A/S) [42].

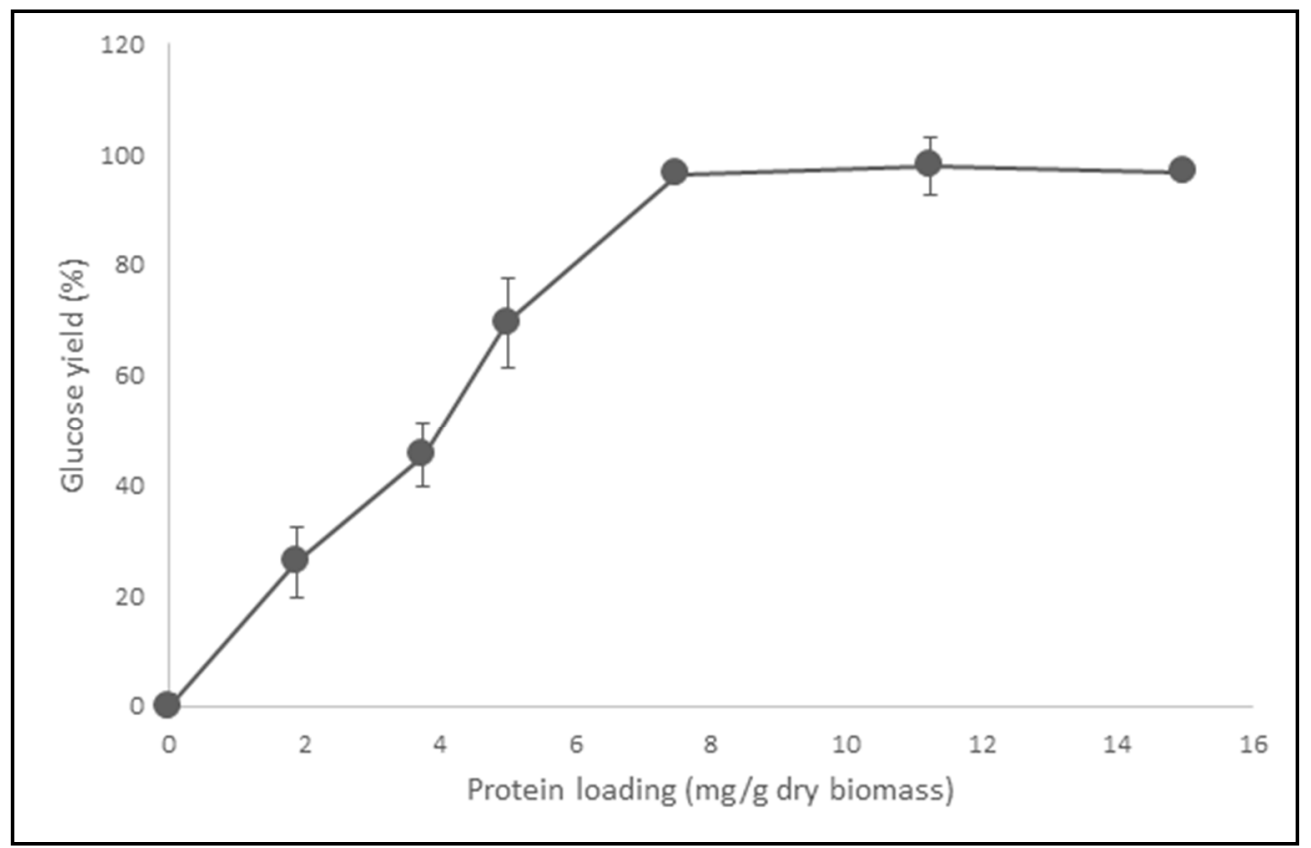

Figure 4. Glucose yield obtained from the hydrolysis of $2 \%(w / v, \mathrm{DM})$ paper sludge for $48 \mathrm{~h}$ at $50{ }^{\circ} \mathrm{C}$ using varying protein loadings (1.875 to $15 \mathrm{mg} / \mathrm{g}$ biomass) of the formulated cellulase cocktail with BGL at $10 \%$ protein loading. All experiments were performed in quadruplicate, and the mean values and error bars $( \pm \mathrm{SD})$ were calculated. The statistical analysis showed that the differences were statistically significant (one-way ANOVA, $p<0.05$ ).

The saccharification ability of the Opt CelMix (108 mg sugars/mg enzyme) on paper sludge was five-fold higher than that (approximately $27.3 \mathrm{mg}$ sugars/mg enzyme) reported by Hu and colleagues with the hydrolysis of steam pretreated corn stover (SPCS) after $72 \mathrm{~h}$ [43] and by Malgas and co-workers with the hydrolysis of steam pre-treated hardwoods after $24 \mathrm{~h}$ [26]. This was not surprising, as some authors promote the amenability of paper sludge for enzymatic hydrolysis compared to raw wood or untreated plant materials since paper sludge generally has negligible quantities of hemicellulose and lignin that contribute to biomass recalcitrance.

\subsection{Scanning Electron Microscopy (SEM)}

SEM visualisation was used to analyse the changes in the size and surface morphology of the paper sludge microfibrils upon cellulase hydrolysis, wherein the $48 \mathrm{~h}$ hydrolysates by the Opt CelMix at $7.5 \mathrm{mg} / \mathrm{g}$ biomass were analysed (Figure 5). The untreated (with no enzyme addition) paper sludge microfibrils are present as thick and long ribbons with a smooth and regular surface (Figure 5A). In contrast, the surface and dimensions of the microfibrils changed significantly after enzyme treatment (Figure 5B). After cellulase treatment, the paper sludge fibrils appeared to have dislocations on the 
surface of the microfibrils. Enzyme treatment of paper sludge microfibrils led to a partial decrease in width, from 19.12 to $13.42 \mu \mathrm{m}$, and a significant reduction in length, from $\geq 2 \mathrm{~mm}$ to $93 \mu \mathrm{m}$.
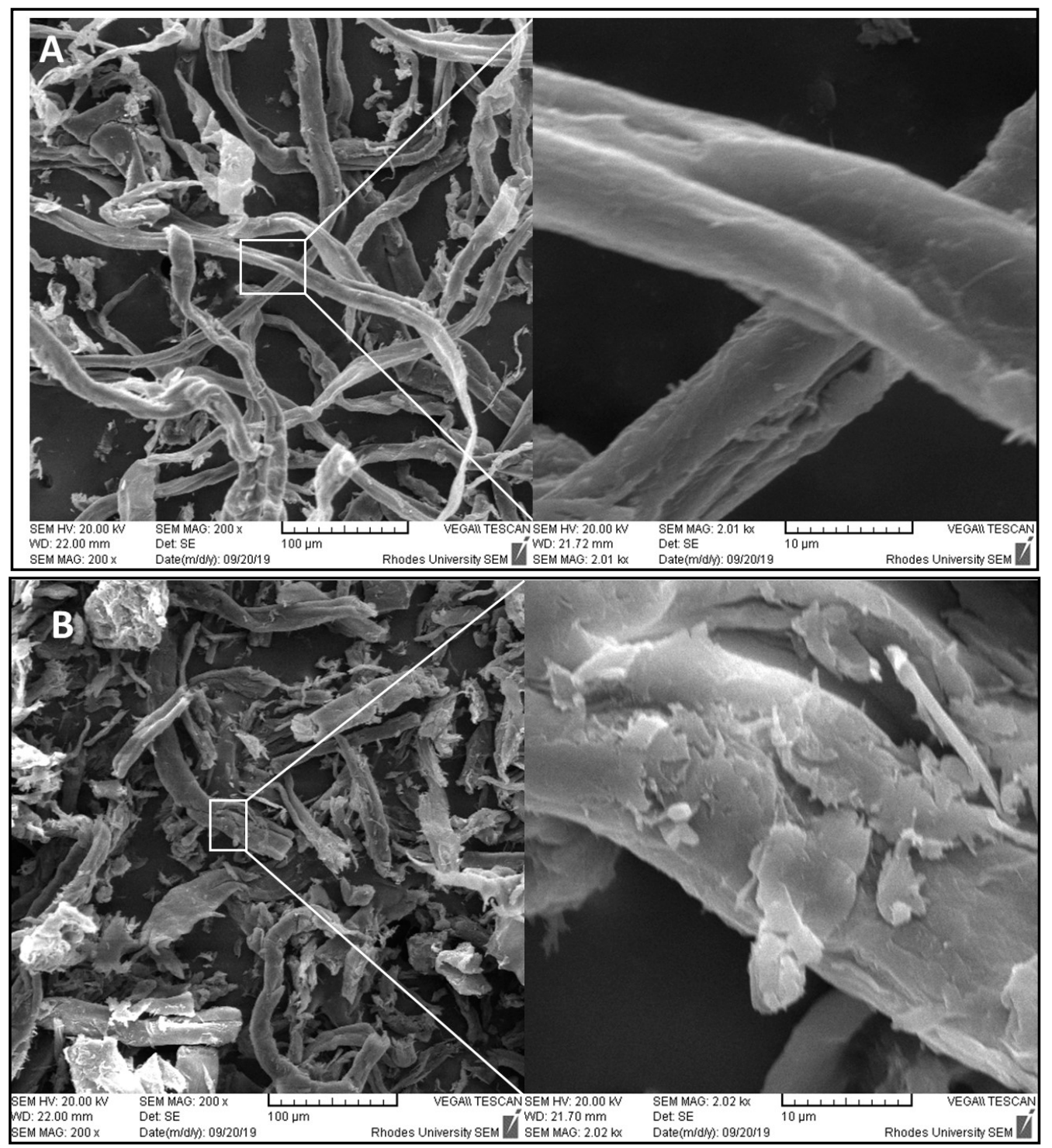

Figure 5. Scanning electron microscopic (SEM) analysis of paper sludge: surface morphology of (A) paper sludge before enzyme treatment and (B) solid residues after enzymatic hydrolysis by the Opt CelMix at a protein loading of $7.5 \mathrm{mg} / \mathrm{g}$ biomass. Two magnifications for each sample were used; $200 \times$ magnification allows the observer to see fibril length reduction while $2000 \times$ magnification allows the observer to see fibril surface erosion upon enzyme hydrolysis.

\subsection{Evaluation of the Performance of the Opt CelMix at Varying Paper Sludge Loadings}

Fermentation processes that produce ethanol at concentrations lower than $4 \%(w / v)$ require subsequent distillation of the product (with an extensive energy consumption) [44]. Therefore, increasing substrate loading during hydrolysis and fermentation steps is essential to make ethanol production economically feasible. Therefore, the performance of the Opt CelMix (at an enzyme dosage of $15 \mathrm{mg} / \mathrm{g}$ biomass) was investigated at various paper sludge loadings (1-20\% w/v) (Figure 6).

The Opt CelMix enzyme cocktail released consistent levels of glucose ( $\sim 80 \%$ yield) across the substrate loadings of 1 to $10 \%$ with a decrease in saccharification yield at higher substrate loadings (Figure 5). Similar to these findings, a study reported approximately $80 \%$ yield for two cocktails; (1) an optimised in vivo thermostable-cellulase mixture and (2) a Cellic CTec $2{ }^{\circledR}$ to Cellic $\mathrm{HTec}{ }^{\circledR}$ mixture, 
during the hydrolysis of $8 \%(w / v)$ steam exploded bagasse [37]. The incomplete hydrolysis at higher paper sludge concentrations could be due to glucose inhibition of the enzymes. This is not a problem during fermentations since the glucose will be utilised by the yeast as its being produced. At 10 to $20 \%(w / v)$ paper sludge loadings, the saccharification yields obtained by Opt CelMix averaged at approximately $90 \mathrm{mg} / \mathrm{mL}$ glucose, this amount being enough to produce in excess of $40 \mathrm{mg} / \mathrm{mL}$ or $4 \%$ $(w / v)$ ethanol.

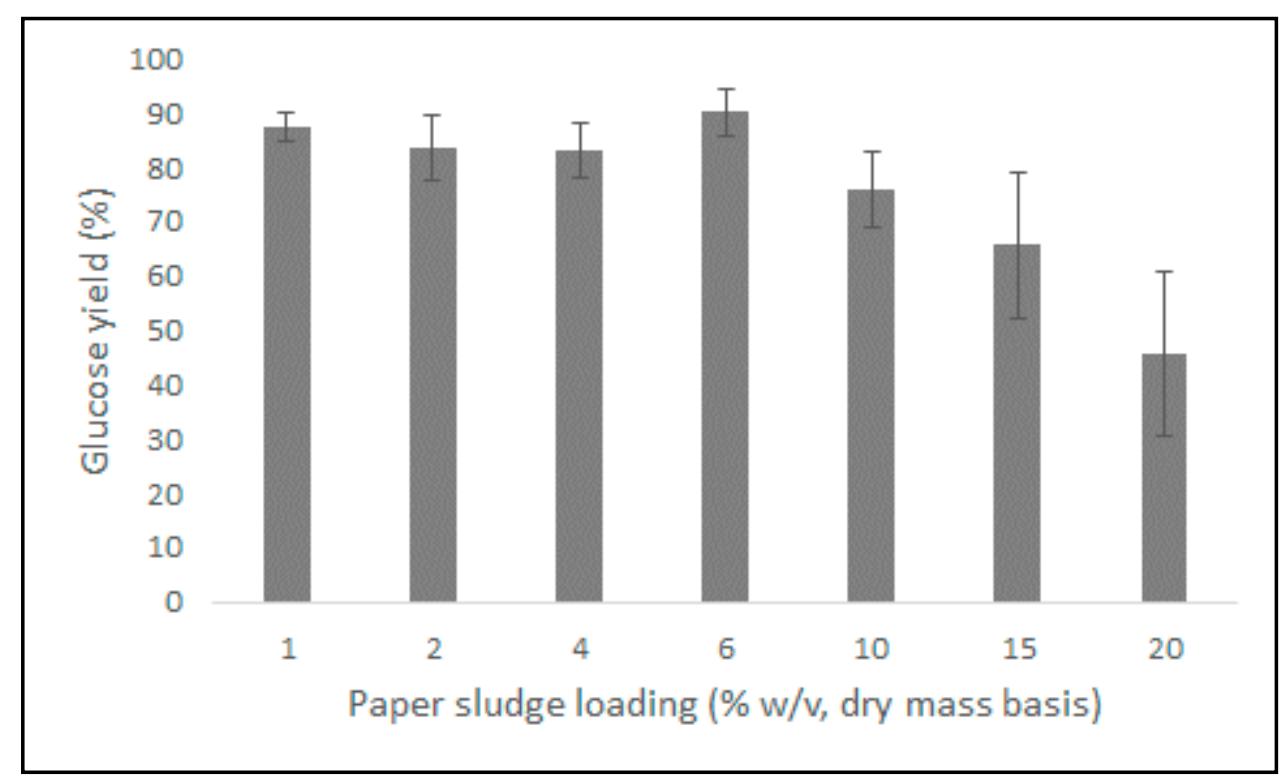

Figure 6. Glucose yield obtained by the action of the formulated cellulase cocktail at $15 \mathrm{mg} / \mathrm{g}$ biomass with BGL at $10 \%$ protein loading during the hydrolysis of varying substrate loadings (1 to $20 \%(w / v)$ ) paper sludge at $50{ }^{\circ} \mathrm{C}$ for $48 \mathrm{~h}$. All experiments were performed in quadruplicate, and the mean values and error bars $( \pm \mathrm{SD})$ were calculated. The statistical analysis showed that the differences were statistically significant (one-way ANOVA, $p<0.05$ ).

The initially high viscosity of lignocellulosic materials at high solid loadings prevents efficient mixing and is associated with poor mass transfer which leads to lowered saccharification of the biomass by the cellulases [45]. For high-water retention materials, such as paper sludge, whereby enzymes have a reduced mobility due to lower free liquid in suspension [46], the Opt CelMix maintained its performance at high solid loads. These results are encouraging with regards to the economic feasibility of using Opt CelMix industrially.

\subsection{Comparison of the Hydrolytic Efficiency of the Opt CelMix to Commercial Cellulase Preparations}

The hydrolytic performance of the Opt CelMix and the commercially available cellulase preparations (Celluclast ${ }^{\circledR} 1.5 \mathrm{~L}$, Cellic ${ }^{\circledR}$ CTec2 and Viscozyme ${ }^{\circledR} \mathrm{L}$ ) were assessed on paper sludge under "optimal" enzymatic conditions ( $\mathrm{pH} 5.0,45 \mathrm{rpm}, 50^{\circ} \mathrm{C}$ ) (Figure 7).

After the first $6 \mathrm{~h}$ of hydrolysis the Opt CelMix, Cellic ${ }^{\circledR} \mathrm{CTec} 2$ and Celluclast ${ }^{\circledR} 1.5$ L displayed a hydrolytic rate of approximately $1.2 \mathrm{mg} / \mathrm{mL} / \mathrm{h}$ glucose, while Viscozyme ${ }^{\circledR} \mathrm{L}$ displayed a rate of $0.35 \mathrm{mg} / \mathrm{mL} / \mathrm{h}$ glucose (Figure 7A). The hydrolysis yields by Opt CelMix and the different commercial cellulase preparations were then evaluated after $48 \mathrm{~h}$. Comparable yields of about $90 \%$ were obtained by the Opt CelMix, Cellic CTec $2^{\circledR}$ and Celluclast ${ }^{\circledR} 1.5 \mathrm{~L}$, while Viscozyme ${ }^{\circledR}$ L displayed a yield of $26.4 \%$ (Figure 7B). High yields from the conversion of paper sludge by the commercial enzymes were expected as a recent study showed that Celluclast ${ }^{\circledR} 1.5 \mathrm{~L}$ displayed a hydrolysis yield of $76.8 \%$ with the hydrolysis of deinking paper sludge [47]. 

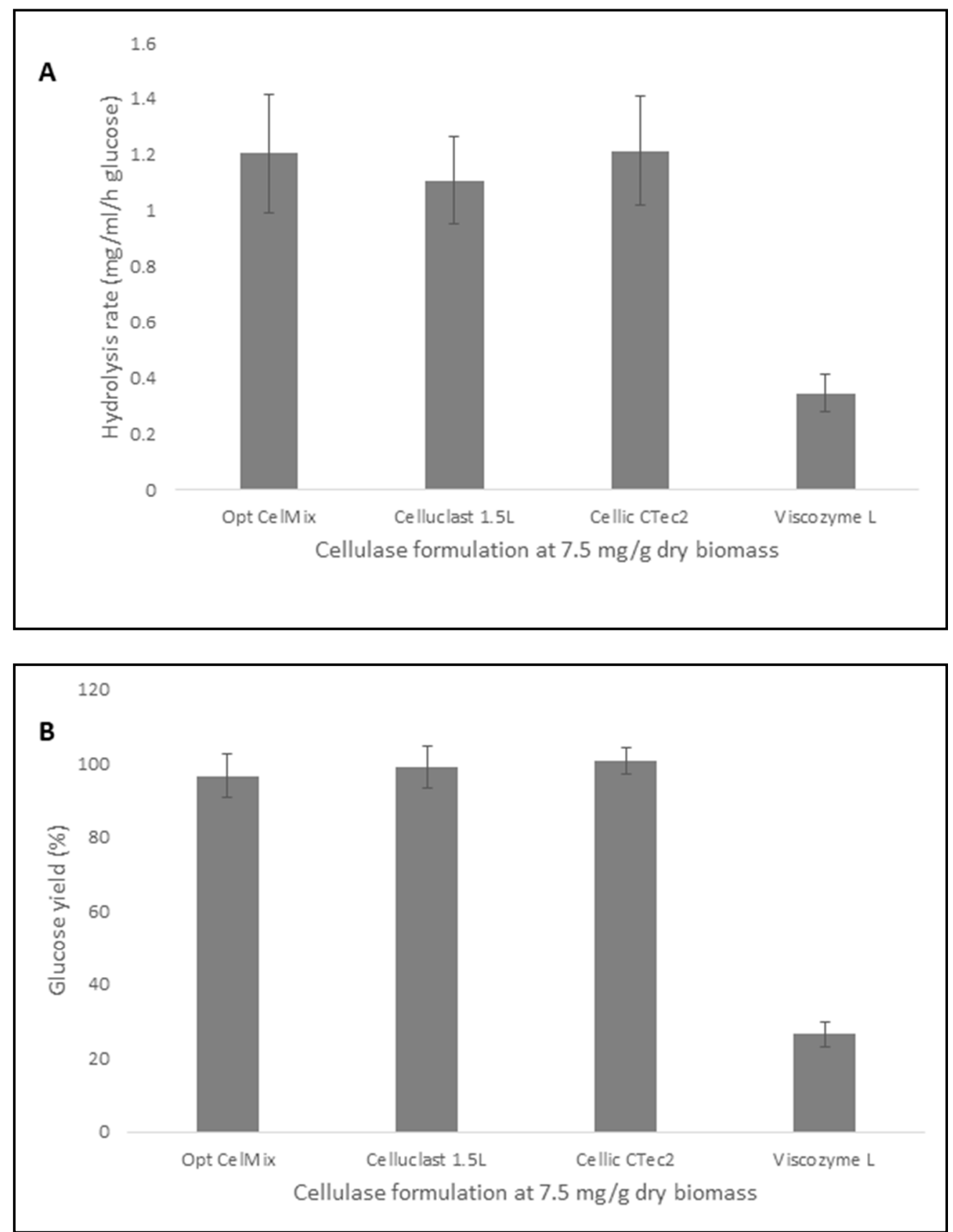

Figure 7. Comparison of (A) hydrolytic rates after $6 \mathrm{~h}$ and $(\mathrm{B})$ glucose yields obtained after $48 \mathrm{~h}$ from the hydrolysis of $2 \%\left(w / v\right.$, dry mass basis) paper sludge for $48 \mathrm{~h}$ at $50{ }^{\circ} \mathrm{C}$ using the Opt CelMix, Celluclast ${ }^{\circledR}$ $1.5 \mathrm{~L}$, Cellic ${ }^{\circledR} \mathrm{CTec} 2$ and Viscozyme ${ }^{\circledR} \mathrm{L}$ at a protein loading of $7.5 \mathrm{mg} / \mathrm{g}$ biomass. All experiments were performed in quadruplicate, and the mean values and error bars $( \pm \mathrm{SD})$ were calculated. The statistical analysis showed that the differences were statistically significant (one-way ANOVA, $p<0.05$ ).

\section{Materials and Methods}

\subsection{Materials}

Paper sludge was derived from Norway spruce (Picea abies) as residual fibre from a sulphite process (Domsjö Fabriker AB refinery, Örnsköldsvik, Sweden). All the chemicals and substrates (Carboxymethyl cellulose (CMC-Na), Avicel, $p$-nitrophenyl-glucopyranoside ( $p N P G$ ) and $p$-nitrophenyl-cellobioside $(p$ NPC $)$ ) were purchased from Sigma Aldrich (St. Louis, MI, USA) unless stated otherwise. The 1, 4- $\beta$-D-cellopentaitol was obtained from Megazyme ${ }^{\mathrm{TM}}$ (Ireland). The enzyme cocktails (Celluclast ${ }^{\circledR}$ 
$1.5 \mathrm{~L}$, Cellic CTec2 ${ }^{\circledR}$ and Viscozyme ${ }^{\circledR}$ L) were supplied by Novozymes A/S (Denmark). Amicon Pro Centrifugal filters $(10 \mathrm{~K})$ were purchased from MERCK (South Africa).

\subsection{Paper Sludge Moisture Content Determination}

Exactly $10 \mathrm{~g}$ of the paper sludge was added to a dry pre-weighed aluminium weighing boat and placed in an oven at $50{ }^{\circ} \mathrm{C}$ until a constant weight was achieved. The \% moisture content of the paper sludge was calculated as follows:

$$
\% \text { moisture content }=\frac{\text { biomass wet weight }- \text { biomass dry weight }}{\text { biomass dry weight }} \times 100 \%
$$

\subsection{Paper Sludge Chemical Composition}

The paper sludge was characterised using a modified sulphuric acid method by the National Renewable Energy Laboratory (NREL) (Golden, CO, USA) [48]. After the two-step acid hydrolysis, the biomass was filtered with the filtrate analysed with regards to acid-soluble lignin (ASL) and monosaccharide content using UV-V is spectroscopy and HPAEC, respectively, while the solid residue was set aside for Klason lignin and ash content estimation. The mass of the solid residue was measured after drying overnight at $105^{\circ} \mathrm{C}$ to estimate the Klason lignin content. The mass of the solid residue used for Klason lignin was ignited in a muffle furnace at $525^{\circ} \mathrm{C}$ for $6 \mathrm{~h}$, cooled in a desiccator, and weighed to determine the ash content of the paper sludge.

\subsection{Paper Sludge Crystallinity Index (CrI)}

The crystallinity of paper sludge was determined by X-ray diffraction using $\mathrm{Cu} \mathrm{K}$ radiation (1.5405 $\AA$, nickel filter) on a Bruker D8 ${ }^{\circledR}$ Discover (Bruker, United Kingdom) equipped with a proportional counter. The sample was scanned from $2 \theta$ of 10 to $40^{\circ}$ with a step size of $0.02^{\circ}$. The determination time was $0.02^{\circ}$ per second. The crystallinity index $(\mathrm{CrI})$ was then defined as follows:

$$
C r I=\frac{I_{002}-I_{a m}}{I_{002}} \times 100
$$

where $I_{002}$ and $I_{a m}$ are the intensities of diffraction at $2 \theta 22.6^{\circ}$ (crystalline portion) and $18.9^{\circ}$ (amorphous portion), respectively.

\subsection{Simon's Staining (SS) of Paper Sludge}

The accessibility of cellulose contained in paper sludge to cellulases was assessed using a modified version of Simon's Stain technique with Direct Orange 15 (DO) dye as an adsorbent as described previously [49]. An increase in the DO dye absorption was proportional to increased cellulose accessibility [50]. SS (mg/g pulp) represents the amount of DO dye absorbed by paper sludge.

\subsection{Media, Yeast Strains and Culture Conditions}

The laboratory S. cerevisiae Y294 strain was used as a parental strain for the constitutive expression of the different cellulase genes. The S. cerevisiae Y294 [TrEGII], Y294 [TeCBHI], Y294 [ClCBHIIb] and Y294 [PCBGLIIB] strains express the recombinant mono-component cellulase genes which produced the Trichoderma reesei endoglucanase II (TrCel5A) [12], the Talaromyces emersonii cellobiohydrolase I (TeCel7A) with a carbohydrate binding module (CBM) attached to its carboxyl terminal (Tecbh1-TrCBM-C [11,12], the Chrysosporium lucknowensis cellobiohydrolase II (ClCel6A) [11] and Phanerochaeta chrysospoprium $\beta$-glucosidase (PcBGL1B) [25], hereafter referred to as EGII, CBHI, CBHII and BGL, respectively.

$\mathrm{SC}^{\text {-URA }}$ growth medium was prepared in double strength $(13.4 \mathrm{~g} / \mathrm{L}$ yeast nitrogen base without amino acids (BD-Diagnostic Systems, Sparks, MD, USA), $20 \mathrm{~g} / \mathrm{L}$ glucose, and $3 \mathrm{~g} / \mathrm{L}$ yeast synthetic dropout medium supplements). The aerobic cultivation of $S$. cerevisiae $\mathrm{Y} 294$ strains was performed 
on a rotary shaker $(200 \mathrm{rpm})$ at $30{ }^{\circ} \mathrm{C}$ in $500 \mathrm{~mL}$ Erlenmeyer flasks containing $100 \mathrm{~mL}$ medium. The supernatant of the individual strains was harvested after $72 \mathrm{~h}$ of cultivation through centrifugation for $10 \mathrm{~min}$ at $4000 \times g$.

\subsection{Preparation of Partially Purified Enzymes}

Approximately $15 \mathrm{~mL}$ of crude cellulase supernatants were ultra-filtrated using an Amicon Ultra-15 Centrifugal device with a $10 \mathrm{kDa}$ cut off membrane. The samples were centrifuged at $4000 \times \mathrm{g}$ for $20 \mathrm{~min}$ at $4{ }^{\circ} \mathrm{C}$ using a swinging-bucket rotor in the Heraeus Megafuge 1.0R (ThermoFischer Scientific, Waltham, MA, USA). The $10 \mathrm{kDa}$ retentate (approximately $0.5 \mathrm{~mL}$ ) were diluted to $1.5 \mathrm{~mL}$ using $50 \mathrm{mM}$ sodium citrate buffer ( $\mathrm{pH}$ ) and stored at $4{ }^{\circ} \mathrm{C}$.

\subsection{Protein Content and Purity Determination}

The protein content of the yeast-derived cellulases was determined by the Bradford method with bovine serum albumin (BSA) used as a suitable protein standard [51]. To determine purity, protein samples were subsequently separated by electrophoresis on denaturing $12 \%$ SDS-PAGE gels according to a protocol described previously [52]. Coomassie Brilliant Blue R-250 staining was used to visualise the gels.

\subsection{Enzyme Assays}

\subsubsection{Substrate Specificity Determination}

The endo-glucanase, cellobiohydrolase II, beta-glucosidase and cellobiohydrolase I activities were determined using the CMC-Na, 1, 4- $\beta$-D-cellopentaitol, $p N P G$ and $p$ NPC substrates, respectively. Standard assay conditions ( $50 \mathrm{mM}$ sodium citrate buffer ( $\mathrm{pH} \mathrm{5.0)}$ ) at $50^{\circ} \mathrm{C}$ with continuous agitation at $45 \mathrm{rpm}$ ) were followed as previously described [26]. One unit (U) of enzyme activity is defined as the amount of enzyme releasing $1 \mu \mathrm{mol}$ of glucose per minute under the specified assay conditions $[6,7]$.

\subsubsection{Enzyme Cocktail Formulation}

The experiments were carried out in quadruplicate at a paper sludge loading of $2 \%(w / v D W)$ in $50 \mathrm{mM}$ sodium citrate buffer ( $\mathrm{pH} 5.0$ ) in a $400 \mu \mathrm{L}$ total volume (with $0.1 \mathrm{mg} / \mathrm{mL}$ BSA as a stabiliser) using $1.5 \mathrm{~mL}$ safe-lock Eppendorf tubes. Hydrolysis took place at $50^{\circ} \mathrm{C}$ with mixing at $45 \mathrm{rpm}$ for up to $48 \mathrm{~h}$. Unless otherwise specified, enzyme loadings were maintained at $1.875 \mathrm{mg} / \mathrm{g}$ paper sludge with BGL at $10 \%$ of the total protein loading $(0.1875 \mathrm{mg} / \mathrm{g}$ paper sludge). The aforementioned enzyme loading was used for the synergy studies as it assured greater than $5 \%$ glucan conversion yields of paper sludge. Binary and ternary combinations between the cellobiohydrolases; CBHI and CBHII, and the endo-glucanase, EGII, were formulated (Table 3).

The optimal combination for glucose release was selected as the "core cellulase cocktail" (Opt CelMix). The hydrolysis was terminated by boiling for $5 \mathrm{~min}$ at $100^{\circ} \mathrm{C}$ to inactivate the enzymes. Hydrolysis controls included substrate (without the enzyme) and enzyme controls (without substrate). The samples were stored at $4{ }^{\circ} \mathrm{C}$ until analysed.

\subsubsection{Effect of Cellulase Cocktail Loading on the Hydrolysis Yields of Paper Sludge}

The hydrolysis of $2 \%(w / v \mathrm{DM})$ paper sludge by the formulated cellulase enzyme cocktail was evaluated at a protein dosage range of $1.875-15 \mathrm{mg}$ protein/g of paper sludge, following the procedure outlined in Section 3.9.2.

\subsubsection{Effect of Paper Sludge Loading on Cellulase Cocktail Hydrolytic Efficiency}

Hydrolysis experiments were carried out at 1\%, 2\%, 4\%, 6\%, 10\%, 15\% and 20\% (w/v) DM consistency using paper sludge at a cellulase cocktail loading of $15 \mathrm{mg} / \mathrm{g}$ of paper sludge to evaluate 
the effect of paper sludge loading on cellulase enzyme cocktail hydrolytic efficiency, following the procedure outlined in Section 3.9.2.

Table 3. Enzyme combinations (\%) at a total protein dosage of $1.875 \mathrm{mg} / \mathrm{g}$ biomass for paper sludge hydrolysis synergy studies with BGL added subsequently at $10 \%$ of the total protein dosage.

\begin{tabular}{cccc}
\hline No & CBHI\% & CBHII\% & EGII\% \\
\hline 1. & 100 & 0 & 0 \\
2. & 75 & 25 & 0 \\
3. & 50 & 50 & 0 \\
4. & 25 & 75 & 0 \\
5. & 0 & 100 & 0 \\
6. & 0 & 75 & 25 \\
7. & 0 & 50 & 50 \\
8. & 0 & 25 & 75 \\
9. & 0 & 0 & 100 \\
10. & 25 & 0 & 75 \\
11. & 50 & 0 & 50 \\
12. & 75 & 0 & 25 \\
13. & 33.3 & 33.3 & 33.3 \\
14. & 33.5 & 33.5 & 25 \\
15. & 12.5 & 12.5 & 75 \\
16. & 18.75 & 56.25 & 25 \\
17. & 56.25 & 18.75 & 25 \\
\hline
\end{tabular}

\subsubsection{Comparison of the Formulated Cellulase Cocktail to Commercial Enzyme Preparations}

The hydrolysis of $2 \%(w / v, D M)$ paper sludge was conducted using the Opt CelMix, Celluclast ${ }^{\circledR}$ $1.5 \mathrm{~L}$, Cellic CTec $2{ }^{\circledR}$ and Viscozyme ${ }^{\circledR} \mathrm{L}$ at a protein loading of $7.5 \mathrm{mg}$ protein/g of paper sludge, following the procedure outlined in Section 3.9.2. Due to the low level of $\beta$-glucosidase activity detected in Celluclast ${ }^{\circledR} 1.5 \mathrm{~L}$ and Viscozyme ${ }^{\circledR} \mathrm{L}$ (data not shown), these enzyme cocktails were supplemented with the $\beta$-glucosidase preparation, Novozyme ${ }^{\circledR} 188$ (Novozymes A/S) at $10 \%$ of the total protein dosage.

\subsection{Analytical Methods}

Quantification of glucose in the hydrolysates was performed upon enzymatic hydrolysis using the glucose oxidase/peroxidase (GOPOD) method (K-GLUC, Megazyme, Ireland), while that of reducing sugars was performed using the DNS method with glucose as a suitable standard as described previously $[26,53]$.

Paper sludge saccharification yield from all the enzymatic hydrolysis reactions was calculated using the following equation:

$$
\text { Saccharification yield }(\%)=\frac{\text { Glucose released } \times 0.9}{\text { Glucan content }} \times 100
$$

\subsection{Scanning Electron Microscopy (SEM)}

Prior to scanning electron microscopy (SEM), paper sludge samples before and after enzymatichydrolysis were mounted on a metal stub, dried using critical point-drying process and coated with a thin layer of gold prior to SEM analysis. The diameters and lengths of the paper sludge microfibrils from SEM images were quantified using the imaging software Image J. Approximately 30 microfibrils representing each sample were randomly and manually picked for diameter and length analysis. 


\subsection{Statistical Analysis}

All statistical analyses were performed on Microsoft Excel 2013 software using one-way ANOVA. A $p$-value of less than 0.05 was considered to indicate statistically significant differences between compared data sets.

\section{Conclusions}

The study evaluated an optimised enzymatic cocktail that had been formulated with recombinant cellulases produced by S. cerevisiae Y294. The performance of the Opt CelMix was comparable to commercial preparations for paper sludge saccharification. At a protein loading of $7.5 \mathrm{mg} / \mathrm{g}$ biomass, over $80 \%$ glucose recovery was obtained using the formulated cellulase enzyme cocktail. When the enzyme cocktail was dosed at $15 \mathrm{mg} / \mathrm{g}$ biomass, it also showed consistent yields with a glucose recovery of $80 \%$ over a substrate loading range of 1 to $10 \%(w / v)$.

Author Contributions: Conceptualization, W.H.v.Z. and B.I.P.; methodology, S.M. and S.H.R.; software, S.M.; validation, S.M., S.H.R., W.H.v.Z. and B.I.P.; formal analysis, S.M., S.H.R., W.H.v.Z. and B.I.P.; investigation, S.M. and S.H.R.; resources, W.H.v.Z. and B.I.P.; data curation, S.M.; writing - original draft preparation, S.M.; writing-review and editing, S.M., S.H.R., W.H.v.Z. and B.I.P.; visualization, S.M.; supervision, W.H.v.Z. and B.I.P.; project administration, W.H.v.Z. and B.I.P.; funding acquisition, W.H.v.Z. and B.I.P. All authors have read and agreed to the published version of the manuscript.

Funding: This research was funded by the Department of Science and Technology (DST), the National Research Foundation of South Africa (Grant Number 86423-Senior SARChI Chair: Biofuels and other Clean Alternative Fuels), Rhodes University and Stellenbosch University for financial support. Any opinion, findings and conclusions or recommendations expressed in this material are those of the author(s) and therefore the NRF does not accept any liability in regard thereto.

Acknowledgments: The authors would like to thank Adnan Cavka (Sekab E-Technology AB, Örnsköldsvik, Sweden) for providing the paper sludge sample from Domsjö Fabriker AB refinery, Örnsköldsvik, Sweden.

Conflicts of Interest: The authors declare no conflict of interest.

\section{References}

1. Prasetyo, J.; Naruse, K.; Kato, T.; Boonchird, C.; Harashima, S.; Park, E.Y. Bioconversion of paper sludge to biofuel by simultaneous saccharification and fermentation using a cellulase of paper sludge origin and thermotolerant Saccharomyces cerevisiae TJ14. Biotechnol. Biofuels 2011, 4, 35. [CrossRef]

2. Gottumukkala, L.D.; Haigh, K.; Collard, F.X.; van Rensburg, E.; Görgens, J. Opportunities and prospects of biorefinery-based valorisation of pulp and paper sludge. Bioresour. Technol. 2016, 215, 37-49. [CrossRef]

3. Mendes, C.V.T.; Cruz, C.H.G.; Reis, D.F.N.; Carvalho, M.G.V.S.; Rocha, J.M.S. Integrated bioconversion of pulp and paper primary sludge to second generation bioethanol using Saccharomyces cerevisiae ATCC 26602. Bioresour. Technol. 2016, 220, 161-167. [CrossRef] [PubMed]

4. Kang, L.; Wang, W.; Lee, Y.Y. Bioconversion of kraft paper mill sludges to ethanol by SSF and SSCF. Appl. Biochem. Biotechnol. 2010, 161, 53-66. [CrossRef] [PubMed]

5. Gomes, D.G.; Serna-Loaiza, S.; Cardona, C.A.; Gama, M.; Domingues, L. Insights into the economic viability of cellulases recycling on bioethanol production from recycled paper sludge. Bioresour. Technol. 2018, 267, 347-355. [CrossRef]

6. Ganner, T.; Bubner, P.; Eibinger, M.; Mayrhofers, C.; Planks, H.; Nidetzky, B. Dissecting and reconstructing synergism: In situ visualization of cooperativity among cellulases. J. Biol. Chem. 2012, 287, 43215-43222. [CrossRef] [PubMed]

7. Kostylev, M.; Wilson, D. A distinct model of synergism between a processive endocellulase (TfCel9A) and an exocellulase (TfCel48A) from Thermobifida fusca. Appl. Environ. Microbiol. 2014, 80, 339-344. [CrossRef] [PubMed]

8. Malgas, S.; Thoresen, M.; van Dyk, S.J.; Pletschke, B.I. Time dependence of enzyme synergism during the degradation of model and natural lignocellulosic substrates. Enzyme Microb. Technol. 2017, 103, 1-11. [CrossRef] 
9. Thoresen, M.; Malgas, S.; Pletschke, B.I. Enzyme adsorption-desorption and evaluation of various cellulase recycling strategies for steam pre-treated Eucalyptus enzymatic degradation. Biomass Convers. Biorefinery 2020. [CrossRef]

10. Rizk, M.; Antranikian, G.; Elleuche, S. End-to-end gene fusions and their impact on the production of multifunctional biomass degrading enzymes. Biochem. Biophys. Res. Commun. 2012, 428, 1-5. [CrossRef]

11. Ilmén, M.; Den Haan, R.; Brevnova, E.; McBride, J.; Wiswall, E.; Froehlich, A.; Koivula, A.; Voutilainen, S.P.; Siika-Aho, M.; La Grange, D.C.; et al. High level secretion of cellobiohydrolases by Saccharomyces cerevisiae. Biotechnol. Biofuels 2011, 4, 30. [CrossRef] [PubMed]

12. Mhlongo, S.I.; den Haan, R.; Viljoen-Bloom, M.; van Zyl, W.H. Lignocellulosic hydrolysate inhibitors selectively inhibit/deactivate cellulase performance. Enzyme Microb. Technol. 2015, 81, 16-22. [CrossRef] [PubMed]

13. den Haan, R.; van Rensburg, E.; Rose, S.H.; Görgens, J.F.; van Zyl, W.H. Progress and challenges in the engineering of non-cellulolytic microorganisms for consolidated bioprocessing. Curr. Opin. Biotechnol. 2015, 33, 32-38. [CrossRef] [PubMed]

14. Davison, S.A.; den Haan, R.; van Zyl, W.H. Heterologous expression of cellulase genes in natural Saccharomyces cerevisiae strains. Appl. Microbiol. Biotechnol. 2016, 100, 8241-8254. [CrossRef]

15. Voutilainen, S.P.; Murray, P.G.; Tuohy, M.G.; Koivula, A. Expression of Talaromyces emersonii cellobiohydrolase Cel7A in Saccharomyces cerevisiae and rational mutagenesis to improve its thermostability and activity. Protein Eng. Des. Sel. 2010, 23, 69-79. [CrossRef]

16. Kroukamp, H.; den Haan, R.; van Zyl, J.-H.; van Zyl, W.H. Rational strain engineering interventions to enhance cellulase secretion by Saccharomyces cerevisiae. Biofuels Bioprod. Biorefining 2018, 12, 108-124. [CrossRef]

17. Davison, S.A.; den Haan, R.; van Zyl, W.H. Exploiting strain diversity and rational engineering strategies to enhance recombinant cellulase secretion by Saccharomyces cerevisiae. Appl. Microbiol. Biotechnol. 2020. [CrossRef]

18. Park, S.; Baker, J.O.; Himmel, M.E.; Parilla, P.A.; Johnson, D.K. Cellulose crystallinity index: Measurement techniques and their impact on interpreting cellulase performance. Biotechnol. Biofuels 2010, 3, 10. [CrossRef]

19. Segal, L.; Creely, J.; Martin, A.; Conrad, C. An empirical method for estimating the degree of crystallinity of native cellulose using the x-ray diffractometer. Text. Res. J. 1959, 29. [CrossRef]

20. Malgas, S.; Kwanya Minghe, V.M.; Pletschke, B.I. The effect of hemicellulose on the binding and activity of cellobiohydrolase I, Cel7A, from Trichoderma reesei to cellulose. Cellulose 2020, 27, 781-797. [CrossRef]

21. Thygesen, A.; Oddershede, J.; Lilholt, H.; Thomsen, A.B.; Ståhl, K. On the determination of crystallinity and cellulose content in plant fibres. Cellulose 2005, 12, 563-576. [CrossRef]

22. den Haan, R.; van Zyl, J.M.; Harms, T.M.; van Zyl, W.H. Modeling the minimum enzymatic requirements for optimal cellulose conversion. Environ. Res. Lett. 2013, 8, 025013. [CrossRef]

23. Tsukada, T.; Igarashi, K.; Yoshida, M.; Samejima, M. Molecular cloning and characterization of two intracellular $\beta$-glucosidases belonging to glycoside hydrolase family 1 from the basidiomycete Phanerochaete chrysosporium. Appl. Microbiol. Biotechnol. 2006, 73, 807-814. [CrossRef]

24. Rath, A.; Glibowicka, M.; Nadeau, V.G.; Chen, G.; Deber, C.M. Detergent binding explains anomalous SDS-PAGE migration of membrane proteins. Proc. Natl. Acad. Sci. USA 2009, 106, 1760-1765. [CrossRef] [PubMed]

25. Njokweni, A.P.; Rose, S.H.; Van Zyl, W.H. Fungal $\beta$-glucosidase expression in Saccharomyces cerevisiae. J. Ind. Microbiol. Biotechnol. 2012, 39, 1445-1452. [CrossRef] [PubMed]

26. Malgas, S.; Chandra, R.; Van Dyk, J.S.; Saddler, J.N.; Pletschke, B.I. Formulation of an optimized synergistic enzyme cocktail, HoloMix, for effective degradation of various pre-treated hardwoods. Bioresour. Technol. 2017, 245, 52-65. [CrossRef]

27. Nakamura, A.; Tsukada, T.; Auer, S.; Furuta, T.; Wada, M.; Koivula, A.; Igarashi, K.; Samejima, M. The tryptophan residue at the active site tunnel entrance of Trichoderma reesei cellobiohydrolase Cel7A is Important for initiation of degradation of crystalline cellulose. J. Biol. Chem. 2013, 288, 13503-13510. [CrossRef] 
28. Zhong, L.; Matthews, J.F.; Hansen, P.I.; Crowley, M.F.; Cleary, J.M.; Walker, R.C.; Nimlos, M.R.; Brooks, C.L.; Adney, W.S.; Himmel, M.E.; et al. Computational simulations of the Trichoderma reesei cellobiohydrolase I acting on microcrystalline cellulose I $\beta$ : The enzyme-substrate complex. Carbohydr. Res. 2009, 344, 1984-1992. [CrossRef]

29. Igarashi, K.; Koivula, A.; Wada, M.; Kimura, S.; Penttila, M.; Samejima, M. High speed atomic force microscopy visualizes processive movement of Trichoderma reesei cellobiohydrolase I on crystalline cellulose. J. Biol. Chem. 2009, 284, 36186-36190. [CrossRef]

30. Hoshino, E.; Shiroishi, M.; Amano, Y.; Nomura, M.; Kanda, T. Synergistic actions of exo-type cellulases in the hydrolysis of cellulose with different crystallinities. J. Ferment. Bioeng. 1997, 84, 300-306. [CrossRef]

31. Väljamäe, P.; Sild, V.; Pettersson, G.; Johansson, G. The initial kinetics of hydrolysis by cellobiohydrolases I and II is consistent with a cellulose surface-erosion model. Eur. J. Biochem. 1998, 253, 469-475. [CrossRef] [PubMed]

32. Wood, T.M.; McCrae, S.I. Synergism Between Enzymes Involved in the Solubilization of Native Cellulose. In Hydrolysis of Cellulose: Mechanisms of Enzymatic and Acid Catalysis; Advances in Chemistry; American Chemical Society: Washington, DC, USA, 1979; Volume 181, pp. 181-209. ISBN 0-8412-0460-8.

33. Jalak, J.; Kurašin, M.; Teugjas, H.; Väljamä, P. Endo-exo synergism in cellulose hydrolysis revisited. J. Biol. Chem. 2012, 287, 28802-28815. [CrossRef] [PubMed]

34. Boisset, C.; Fraschini, C.; Schülein, M.; Henrissat, B.; Chanzy, H. Imaging the enzymatic digestion of bacterial cellulose ribbons reveals the endo character of the cellobiohydrolase Cel6A from Humicola insolens and its mode of synergy with cellobiohydrolase Cel7A. Appl. Environ. Microbiol. 2000, 66, 1444-1452. [CrossRef] [PubMed]

35. Boisset, C.; Pétrequin, C.; Chanzy, H.; Henrissat, B.; Schlein, M. Optimized mixtures of recombinant Humicola insolens cellulases for the biodegradation of crystalline cellulose. Biotechnol. Bioeng. 2001, 72, 339-345. [CrossRef]

36. Woodward, J.; Lima, M.; Lee, N.E. The role of cellulase concentration in determining the degree of synergism in the hydrolysis of microcrystalline cellulose. Biochem. J. 1988, 255, 895-899. [CrossRef] [PubMed]

37. Kallioinen, A.; Puranen, T.; Siika-Aho, M. Mixtures of thermostable enzymes show high performance in biomass saccharification. Appl. Biochem. Biotechnol. 2014, 173, 1038-1056. [CrossRef]

38. Väljamäe, P.; Sild, V.; Nutt, A.; Pettersson, G.; Johansson, G. Acid hydrolysis of bacterial cellulose reveals different modes of synergistic action between cellobiohydrolase I and endoglucanase I. Eur. J. Biochem. 1999, 266, 327-334. [CrossRef]

39. Zhang, Y.H.P.; Lynd, L.R. A functionally based model for hydrolysis of cellulose by fungal cellulase. Biotechnol. Bioeng. 2006, 94, 888-898. [CrossRef]

40. Zhang, Y.H.P.; Lynd, L.R. Determination of the number-average degree of polymerization of cellodextrins and cellulose with application to enzymatic hydrolysis. Biomacromolecules 2005, 6, 1510-1515. [CrossRef]

41. Zhou, J.; Wang, Y.H.; Chu, J.; Luo, L.Z.; Zhuang, Y.P.; Zhang, S.L. Optimization of cellulase mixture for efficient hydrolysis of steam-exploded corn stover by statistically designed experiments. Bioresour. Technol. 2009, 100, 819-825. [CrossRef]

42. Przybysz Buzała, K.; Kalinowska, H.; Przybysz, P.; Małachowska, E. Conversion of various types of lignocellulosic biomass to fermentable sugars using kraft pulping and enzymatic hydrolysis. Wood Sci. Technol. 2017, 51, 873-885. [CrossRef]

43. Hu, J.; Arantes, V.; Saddler, J.N. The enhancement of enzymatic hydrolysis of lignocellulosic substrates by the addition of accessory enzymes such as xylanase: Is it an additive or synergistic effect? Biotechnol. Biofuels 2011, 4, 36. [CrossRef] [PubMed]

44. Huang, W.D.; Percival Zhang, Y.H. Analysis of biofuels production from sugar based on three criteria: Thermodynamics, bioenergetics, and product separation. Energy Environ. Sci. 2011, 4, 784-792. [CrossRef]

45. Mukasekuru, M.R.; Hu, J.; Zhao, X.; Sun, F.F.; Pascal, K.; Ren, H.; Zhang, J. Enhanced high-solids fed-batch enzymatic hydrolysis of sugar cane bagasse with accessory enzymes and additives at low cellulase loading. ACS Sustain. Chem. Eng. 2018, 6, 12787-12796. [CrossRef]

46. Gomes, D.; Gama, M.; Domingues, L. Determinants on an efficient cellulase recycling process for the production of bioethanol from recycled paper sludge under high solid loadings. Biotechnol. Biofuels 2018, 11, 111. [CrossRef] 
47. Steffen, F.; Janzon, R.; Saake, B. Enzymatic treatment of deinking sludge-effect on fibre and drainage properties. Environ. Technol. 2018, 39, 2810-2821. [CrossRef]

48. Sluiter, J.B.; Ruiz, R.O.; Scarlata, C.J.; Sluiter, A.D.; Templeton, D.W. Compositional analysis of lignocellulosic feedstocks. 1. Review and description of methods. J. Agric. Food Chem. 2010, 58, 9043-9053. [CrossRef]

49. Chandra, R.; Ewanick, S.; Hsieh, C.; Saddler, J.N. The characterization of pretreated lignocellulosic substrates prior to enzymatic hydrolysis. Biotechnol. Prog. 2008, 24, 1178-1185. [CrossRef]

50. Chandra, R.P.; Saddler, J.N. Use of the Simons' staining technique to assess cellulose accessibility in pretreated substrates. Ind. Biotechnol. 2012, 8, 230-237. [CrossRef]

51. Bradford, M.M. A rapid and sensitive method for the quantitation of microgram quantities of protein utilizing the principle of protein-dye binding. Anal. Biochem. 1976, 72, 248-254. [CrossRef]

52. Laemmli, U.K. Cleavage of Structura 1 Proteins during the Assembly of the Head of Bacteriop hage T4. Nature 1970, 227, 680-685. [CrossRef]

53. Miller, G.L. Use of Dinitrosalicylic Acid Reagent for Determination of Reducing Sugar. Anal. Chem. 1959, 31, 426-428. [CrossRef]

(C) 2020 by the authors. Licensee MDPI, Basel, Switzerland. This article is an open access article distributed under the terms and conditions of the Creative Commons Attribution (CC BY) license (http://creativecommons.org/licenses/by/4.0/). 